\title{
Short-term effects of a spinosyn's family insecticide on energy metabolism and liver morphology in frugivorous bats Artibeus lituratus (Olfers, 1818)
}

\author{
Amaral, TS. ${ }^{a}$, Carvalho, TF. ${ }^{a}$, Silva, MC. ${ }^{b}$, Barros, MS. ${ }^{a}$, \\ Picanço, MC..$^{a}$, Neves, $C A .^{b}$ and Freitas, MB. ${ }^{a *}$ \\ aDepartamento de Biologia Animal, Universidade Federal de Viçosa - UFV, \\ Av. Peter Henry Rolfs, s/n, CEP 36570-000, Viçosa, MG, Brazil \\ ${ }^{\text {b}}$ Departamento de Biologia Geral, Universidade Federal de Viçosa - UFV, \\ Av. Peter Henry Rolfs, s/n, CEP 36570-000, Viçosa, MG, Brazil \\ *e-mail: mfreitas@ufv.br \\ Received May 11, 2011 - Accepted June 27, 2011 - Distributed May 31, 2012
}

(With 1 figure)

\begin{abstract}
A new class of insecticide derived from fermentation of Sacharopolyspora spinosa - spinosad, has been indicated as being of low toxicity and a natural alternative to classical pesticides. In order to elucidate several aspects related to the morphophysiological changes induced by spinosad in Artibeus lituratus, the effects of a seven-day administration on plasma glucose, glycogen, protein and lipid concentrations were evaluated, and possible changes in liver cells were examined by histological analysis. Animals were fed with spinosyn-contaminated fruit through immersion in a solution. Data reporting on metabolism revealed a decrease in hind limb muscle lipid concentration in the treated group. Morphological analysis indicated a significant increase in liver cell diameter in treated animals compared to the control group. This study indicates that spinosyn, used at its recommended dose, does not affect general energy metabolism in A. lituratus but may affect some ultrastructural characteristics of liver cells.
\end{abstract}

Keywords: Chiroptera, Artibeus, glycaemia, hepatocyte, pesticide.

\section{Efeitos em curto prazo de inseticida da família das espinosinas sobre o metabolismo energético e a morfologia hepática em morcegos frugívoros}

\begin{abstract}
Resumo
Uma nova classe de inseticida derivado da fermentação de Sacharopolyspora spinosa - espinosade - tem sido indicada como uma alternativa natural de baixa toxicidade aos agrotóxicos clássicos. A fim de elucidar diversos aspectos relacionados às mudanças morfofisiológicas induzidas por espinosade Artibeus lituratus, os efeitos da administração durante sete dias sobre a glicose plasmática, proteína de glicogênio, e as concentrações de lipídios foram avaliados, assim como possíveis alterações nas células do fígado foram examinadas por análise histológica. Os animais foram alimentados com frutas contaminadas com espinosade por meio de imersão em uma solução. Os dados sobre o metabolismo revelaram um decréscimo na concentração de lipídios dos músculos das patas posteriores dos animais do grupo tratado. A análise morfológica indicou um aumento significativo no diâmetro das células do fígado dos animais tratados em relação ao controle. Este estudo indica que o espinosade, utilizado na dose recomendada, não afeta o metabolismo energético em geral de A. lituratus, mas pode afetar algumas características ultraestruturais das células hepáticas.
\end{abstract}

Palavras-chave: Chiroptera, Artibeus, glicemia, hepatócito, pesticida. 


\section{Introduction}

Dispersal of plant seeds by animals is a fundamental part of successful change in the tropics. In this context, frugivorous bats play a critical role in forest regeneration, and its ecological service emphasizes these species current conservation implications (Muscarella and Fleming, 2007).

Habitat loss (Melo et al., 2012) and pesticides are among the possible threats to bat populations. Agriculture not only clears land of bat habitats but also makes heavy use of pesticides; certain bat species have already been seriously impacted leading to them being given threatened or endangered status (Mispagel et al., 2004).

A new class of chemical insecticides obtained from the fermentation of the bacterium Sacharopolyspora spinosa (Actinomycetales) has been indicated as a natural alternative to classical pesticides. A mixture of metabolites of $S$. spinosa (spinosyns A and D) (Mertz and Yao, 1990; Thompson et al., 2000; Yano et al., 2002; Kirst, 2010) present a unique mode of action through nervous system activation of nicotinic and GABA ( $\gamma$-amino butyric acid) receptors (Kirst et al., 1992; DeAmicis et al., 1997; Salgado, 1998; Salgado et al., 1998; Thompson et al., 2000). This mechanism differs from that induced by other nicotinic receptor-based insecticides and macrocyclic lacton (Thompson et al., 2000), which cause a decrease in acetilcholinesterase activity and alter energetic metabolism, promoting effects including hyperglycemia (Hanley Junior et al., 2002; Abdollahi et al., 2004).

Insecticides from the spinosyns class are used mainly in cotton, potato, fruiting plant and tobacco farming and in leaflet vegetable culture and show significant efficacy against target organisms even at low concentrations. It has also been reported that spinosyns present low toxicity to most beneficial insects, as well as to mammals and birds, and may be degraded rapidly in the environment. This suggests that these compounds should be capable of replacing some more toxic insecticides in the control of certain pests (Kirst et al., 1992; DeAmicis et al., 1997; Thompson et al., 2000; Cisneros et al., 2002; Kirst, 2010).

Many wild species may be exposed to significant levels of pesticides, including Artibeus species fruit-eating bats. Due to the ecological importance of these species, considered key for tropical forest dynamics (Garcia et al., 2000), a further threat to their life in the wild could significantly impact the natural balance of ecosystems such as the Atlantic Forest (Timm, 1994; Reis, 2007). Although some pesticide residues have been found in wild bat tissues, no study conducted so far has proposed to assess the physiological parameters related to pesticide toxicity in a bat species (Hamilton-Smith, 2000). Furthermore, several other classes of agrochemical substances, including spinosyns, are still less investigated as regards their effects on metabolic and cellular processes in wild animals. Metabolic processes act mainly to produce a constant supply of energy to cells, by mechanisms of synthesis and degradation of compounds in the body or body reserves, and thus it is important to understand the changes caused by the contact/ingestion of insecticides by wild animals. For these reasons our study aimed at assessing the effects of the intake of spinosyncontaminated fruits on energy metabolism and morphology of liver cells of frugivorous bats.

\section{Material and Methods}

\subsection{Pesticides}

The present study tested a mixture of insecticide spinosyn $\mathrm{A}\left(\mathrm{C}_{42} \mathrm{H}_{67} \mathrm{NO}_{16}\right)$ and spinosyn $\mathrm{D}\left(\mathrm{C}_{41} \mathrm{H}_{65} \mathrm{NO}_{16}\right)$, in a ratio of approximately $85: 15,(480 \mathrm{ppm})$, with the alkyl phenol polyoxyethylene ether (200 ppm) as the adhesive spreader.

\subsection{Animals and treatment}

Adult male bats (Artibeus lituratus) were captured using mist nets on the campus of the Federal University of Viçosa, Viçosa-MG, Brazil (20 $45^{\prime} \mathrm{S}$ and $\left.42^{\circ} 52^{\prime} \mathrm{W}\right)$. Animals (64-73 g body weight) were kept in individual steel cages $(48.4 \times 34.1 \times 23.5 \mathrm{~cm})$ at room temperature and with a natural day-night cycle through a window. After two days of acclimation to the captivity fed ad libitum, bats were separated randomly into two groups: a control group, fed with fruits treated only with the adhesive spreader $(n=6)$ and a treated group, fed with treated fruits $(\mathrm{n}=7)$, for 7 nights. While still whole, papaya ( $\approx 400 \mathrm{~g}$ ) was immersed in syrup solutions containing $10 \%$ adhesive spreader containing concentrations of 3 and $0,1 \mathrm{~mL} / \mathrm{L}$ of the insecticide. Treated fruits were kept suspended in a modified container so that they would not come into contact with any surface and lose the pesticide layer. The concentrations used were those prescribed by the manufacturer for application in fruit cultures. The fruits were divided in half (approximately $200 \mathrm{~g}$ ) and offered to the animals with the skin side up so that during ingestion the bats would be in direct contact with insecticide. The fruit was offered every night around 1800 hour, and water was available ad libitum.

\subsection{Tissue procedures}

At the end of each treatment, animals were euthanised by decapitation, and their blood was collected in heparinised tubes. Tissues (liver, hind limb and forelimb muscles, breast muscle and adipose tissue) were removed, weighed and divided into sub-samples weighing $\geq 200 \mathrm{mg}$ for each analysis and frozen at $-20{ }^{\circ} \mathrm{C}$. The plasma glucose concentration was determined by the glucose-oxidase method. The concentrations of liver and muscle glycogen were determined by placing tissues in tubes containing $2 \mathrm{~mL}$ of $\mathrm{KOH}(30 \%)$ following the methods of Sjörgren et al. (1938). To determine the total liver and muscle (breast, hind limb and forelimb muscle) protein content, a known portion from these tissues (>200 mg) was homogenised in sodium chloride solution $(0.9 \%)$ and submitted to the colorimetric method through the Protein Assay Reagent kit (BCA-PIERCE). To determine total lipid levels in liver, muscles (breast and limbs) and adipose tissue, these 
tissues were homogenized with a chloroform-methanol solution (2:1 v/v) (Folch et al., 1957). After filtration and separation of the phases by the addition of sodium chloride solution $(0.9 \%)$, an aliquot of the chloroform phase $(10 \mathrm{~mL})$ was used to gravimetrically determine the total lipid concentration. Total carcass fatty acids were determined after removal of the digestive tract, from the terminal portion of the esophagus to the anus, kidneys and reproductive apparatus. Carcasses were weighed and digested in $200 \mathrm{~mL}$ of $6 \mathrm{~N} \mathrm{KOH}$ for four to six days and later filtered. Next, an equal volume of absolute alcohol was added, resulting in a solution of $50 \% \mathrm{KOH}$-ethanol $(\mathrm{v} / \mathrm{v})$. A sample of this solution was washed three times with $40 \mathrm{~mL}$ of petroleum ether in a beaker $(100 \mathrm{~mL})$ and the superior phase was suctioned through a vacuum pump. The solution was acidified with $5 \mathrm{~mL}$ of $\mathrm{H}_{2} \mathrm{SO}_{4}$ and subjected to extraction by chloroform with three times the final volume. An aliquot of $50 \mathrm{~mL}$ of this phase was used to determine the total fatty acids by the gravimetric method.

\subsection{Histological analysis}

Liver portions were collected and immediately fixed in Carson-Formalin. The fragments went through a standard dehydration procedure and were embedded in glycol methacrylate (Historesin ${ }^{\circledR}$, Leica). A series of $2 \mu \mathrm{m}$-thick sections were made and the preparations were stained with toluidine blue/sodium borate $1 \%$. Sections were examined using a light microscope with a $40 \times$ objective. Cell diameter and nuclear area were determined using the program Image-Pro Plus 4.5.

\subsection{Statistical analysis}

Data is presented as Mean \pm Standard Error of the Mean (SEM). The $t$-test was applied for results analysis purposes. The Mann-Whitney test was used for non parametric data and the criterion of significance was set at $5 \%(\mathrm{p}<0.05)$.

\section{Results}

\subsection{Plasma glucose}

No change in the plasma glucose concentration $(\mathrm{mmol} / \mathrm{L})$ was observed in animals treated with spinosyn $(6.87 \pm 0.79)$ compared to the control group $(7.66 \pm 1.14)$ (Table 1).

\subsection{Muscle and liver glycogen}

No significant differences were observed in liver and muscle glycogen concentrations ( $\mu$ mol glucosil units/g) (Table 1).

\subsection{Total protein concentration}

Total protein concentrations ( $\mathrm{g} / 100 \mathrm{~g}$ ) did not significantly differ between the groups involved, as shown in Table 2 .

\subsection{Total lipids}

Following the analysis, total lipid concentrations $(\mathrm{g} / 100 \mathrm{~g})$ in breast muscle $(6.61 \pm 0.44$ and $6.73 \pm 0.51)$ and liver $(5.69 \pm 0.47$ and $7.46 \pm 1.35)$ showed no significant differences between groups. Similarly, forelimb muscle lipids $(5.51 \pm 0.50$ and $4.43 \pm 0.56)$ and adipose tissue lipids $(53.63 \pm 1.20$ and $39.91 \pm 6.34)$ showed no significant differences between the groups. Hind limb muscle lipids ( $7.01 \pm 0.31$ and $4.26 \pm 0.83$ ) were decreased in animals exposed to spynosin compared to the control group $(\mathrm{p}<0.05)$ (Table 1$)$.

\subsection{Morphometric measurements}

Hepatic tissue from control animals presented the standard histological structure for mammals, with hepatic cords and lobules normally arranged, as well as blood vessels. The hepatocytes did not contain lipid droplets in the cytoplasm. The mean cellular diameter was $16.83 \pm 0.25 \mu \mathrm{m}$ and the mean nuclear area was $33.02 \pm 2.62 \mu \mathrm{m}^{2}$. In the group exposed to the insecticide spinosyn, liver cell diameter showed a $16 \%$ increase $(19.47 \pm 0.26 \mu \mathrm{m})$ although no significant differences were found in nuclear area $\left(33.29 \pm 1.58 \mu \mathrm{m}^{2}\right)$ as compared to control. We also observed a cytoplasmic vacuolisation in hepatocytes from the treated animals (Figure 1).

Table 1. Total reserve concentration of tissues and plasma glucose evaluated in the control group and in the group exposed to spinosyn insecticide.

\begin{tabular}{lcccccccc}
\hline & Plasma & \multicolumn{2}{c}{ Glycogen } & \multicolumn{5}{c}{ Total lipid } \\
\cline { 3 - 9 } & glucose & BM & LI & HM & FM & BM & LI & AT \\
\hline Control & $7,66 \pm 1,14$ & $0,30 \pm 0,03$ & $6,86 \pm 1,17$ & $7,01 \pm 0,31$ & $5,51 \pm 0,50$ & $6,61 \pm 0,44$ & $5,69 \pm 0,47$ & $53,63 \pm 1,20$ \\
Spinosyn & $6,87 \pm 0,79$ & $0,65 \pm 0,23$ & $7,24 \pm 1,21$ & $4,26 \pm 0,83^{*}$ & $4,43 \pm 0,56$ & $6,73 \pm 0,51$ & $7,46 \pm 1,35$ & $39,91 \pm 6,34$ \\
\hline
\end{tabular}

Plasma glucose concentration (mmol/L); liver and breast muscle glycogen concentrations ( $\mu$ mol glucosil units/g) and Total lipid concentration in hind limb muscle (HM), forelimb muscle (FM) and breast muscle (BM), liver (LI) and adipose tissue (AT) $(\mathrm{g} / 100 \mathrm{~g})$. Figures expressed in Mean \pm EPM. *Significantly different from control.

Table 2. Total protein concentration of tissues evaluated in the control group and in the group exposed to spinosad insecticide $(\mathrm{g} / 100 \mathrm{~g})$.

\begin{tabular}{lcccc}
\hline & Forelimb muscles & Hind limb muscles & Liver & Breast muscle \\
\hline Control & $7.46 \pm 0.41$ & $8.70 \pm 0.96$ & $11.43 \pm 1.37$ & $9.17 \pm 0.82$ \\
Spinosyn & $9.54 \pm 0.85$ & $6.69 \pm 0.55$ & $12.80 \pm 0.86$ & $10.50 \pm 0.77$ \\
\hline
\end{tabular}

Figures expressed in Mean \pm EPM. 

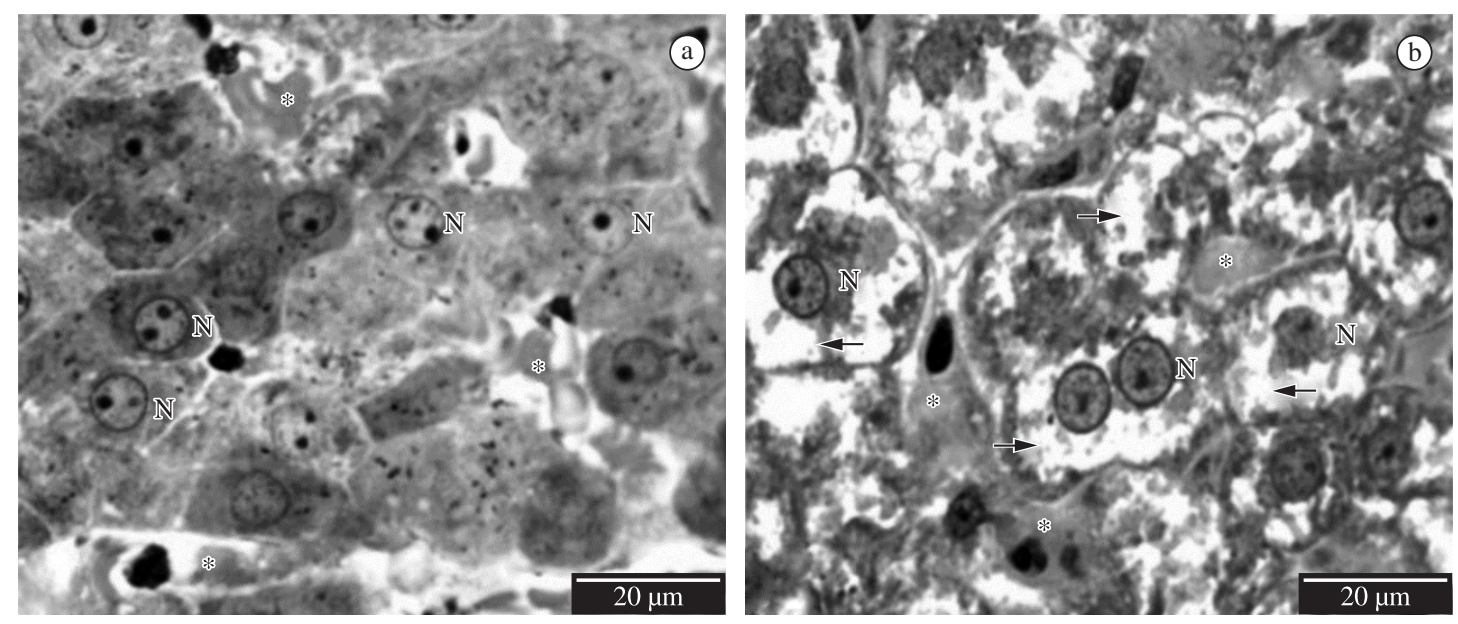

Figure 1. Photomicrography of histological sections of the Artibeus lituratus. Liver, stained with $1 \%$ toluidine blue. a) Control, b) Spinosyn. Nucleus (N), blood vessel $(*)$, vacuolisation $(\rightarrow)-20 \mu \mathrm{m}$.

\section{Discussion}

Wild species are potentially exposed to a large variety of environmentally active concentrations of pesticides. However, to our knowledge, this is the first study to investigate morphophysiological changes induced by a natural pesticide in a fruit-eating bat species at environmentally realistic exposure levels.

The assessment of metabolic parameters of fruit-eating bats treated with spinosyn-contaminated food indicates that this insecticide does not appear to be associated with the mammalian glycemic homeostasis regulatory mechanisms. Plasma glucose level is the first sign of changes in energy balance, as several energetic compounds may be converted into glucose to provide energy to cells (Nordlie et al., 1999). Several organophosphorous pesticides widely used in fruit growing are reported to induce hyperglycemia in mammals (Rahimi and Abdollahi, 2007), activating glycogenolysis and gluconeogenesis and interfering with energy metabolism as well as with several organs and systems (Pournourmohammadi et al., 2005; Rezg et al., 2007). Similar results were found in our previous studies with bats (unpublished data). A comparison of spinosyns with other classes of pesticides shows that this compound is safer to the environment and non-target organism, as its mechanism of action differs from other classes of macrocyclic lactones and from insecticides that act on nicotine receptors. In this study, spinosyns had no effect on glycemic levels. Similarly, bats treated with spinosyns for a seven day period did not show changes in glycogen content or in liver and muscle contents. This result indicates that there is no interference of spinosyn with the regulatory mechanisms of carbohydrates reserves in Artibeus lituratus.

Similar to the results found for plasma glucose levels, liver and muscle protein concentrations did not show changes in spinosyn exposed animals. In the case of lipid reserves, fat concentrations in most of the tested tissues also appear not to be impacted by spinosyn as no changes in contents were observed. The exception to this was in forelimb muscles which showed a significant decrease in lipid levels in treated animals.

Morphometric analyses, however, showed an increase in liver cell diameter, probably due to water accumulation promoting vacuolisation, which leads to cell hypertrophy. Abnormal amounts of intracellular substances can be a manifestation of metabolic disturbances potentially leading to chronic cell injuries and even to cellular death. This hydropic degeneration characterised by electrolyte and water accumulation inside hepatocytes is a non-lethal and very common injury that occurs as a response to several kinds of damage (Pereira, 1993).

Some few studies related to spinosyns-contamined mammals report small changes in the weight of some organs including liver, heart, kidneys and spleen. However, these results are only from animals treated with high dosages $(100 \mathrm{mg} / \mathrm{kg} /$ day $)$ of this pesticide (Hanley Junior et al., 2002). Other studies evaluating the carcinogenic potential of spinosyn in rats also reveal risks for this insecticide class, indicating that cellular changes become more abundant (inflammation and cellular degeneration with or without regeneration) as dosage increases (3-300 mg/kg/day) (Yano et al., 2002). Studies conducted with pregnant female rats and rabbits exposed to spinosyn show that the animals did not suffer body weight changes, both for mothers and fetuses, in addition to absence of changes in development and weight of several organs (for example, liver and brain), with some punctual disturbances being reported again only in cases of exposure to high dosage (200 and $50 \mathrm{mg} / \mathrm{kg} /$ day for rats and rabbits, respectively) (Breslin et al., 2000). However, the dosages associated with these disturbances are not always applied in agriculture, which seems to indicate that low-dosage spinosyn does not seem to damage non target mammal. In a study with sheep, Rothwell et al. (2005) showed that residues of the spinosyns-based formulations were found in adipose tissue and even in organs such as the liver, kidneys and muscles. However, the amount accumulated was only $20 \%$ of the maximum allowed for the consumption of meat 
from those animals. Another important point is that rates of pesticide residues in the body began to decline after 14 days. So even when accumulated in the body, these compounds are at very low concentrations, which may be why no effects were observed in the energy metabolism of bats evaluated in our study. Besides these factors, several other studies claim that spinosyns pesticides have no toxic effects to birds and mammals even in tests of exposure or chronic contamination, since no effects were carcinogenic, teratogenic, mutagenic, or neurotoxic (Thompson et al., 2000; Sparks et al., 2001; Rothwell et al., 2005; Salgado and Sparks, 2005; Kirst 2010). This low toxicity may be explained by the fact that spinosyns have also been found to undergo facile metabolism in several mammals and fowl (Salgado and Sparks, 2005; Rothwell et al., 2005). Overall, the spinosyns are readily subject to a number of diverse degradative pathways and metabolic mechanisms that reduce their persistence in plants, animals and the environment (Kirst, 2010).

\section{Conclusion}

To conclude, we demonstrate that spinosyn insecticides, as an alternative natural compound to classical insecticides, have little effect on glucose homeostasis or storage of energy in frugivorous bats (A. lituratus) at its recommended dose. Further investigations are needed to confirm the lower risk of this class of pesticide for non-target organisms such as wild animals and to explore other factors associated with effects caused by this pesticide.

Acknowledgements - This work was supported by the Fundação de Amparo à Pesquisa do Estado de Minas Gerais (FAPEMIG). We thank B. Freitas and Thomas C. R. Williams for revising the English version.

\section{References}

ABDOLLAHI, M., DONYAVI, M., POURNOURMOHAMMADI, S. and SAADAT, M., 2004. Hyperglycemia associated with increased hepatic glycogen phosphorylase and phosphoenolpyruvate carboxykinase in rats following subchronic exposure to malathion. Comparative Biochemistry and Physiology C-Toxicology \& Pharmacology, vol. 137, p. 343-347.

BRESLIN, WJ., MARTY, MS., VEDULA, U., LIBERACKI, AB. and YANO, BL., 2000. Developmental toxicity of Spinosad administered by gavage to CD1 rats and New Zealand White rabbits. Food and Chemical Toxicology, vol. 38, p. 1103-1112. http://dx.doi.org/10.1016/S0278-6915(00)00108-3

CISNEROS, J., GOULSON, D., DERWENT, LC., PENAGOS, DI. and HERNÁNDEZ, O., 2002. Toxic effects of spinosad on predatory insects. Biological Control, vol. 23, p. 156-163. http:// dx.doi.org/10.1006/bcon.2001.1000

DEAMICIS, CV., DRIPPS, JE., HATTON, CJ. and KARR, LL., 1997. Physical and biological properties of the spinosyns: Novel macrolide pest-control agents from fermentation. In HEDIN, PA., HOLLINGWORTH, RM., MASLER, EP., MIYAMOTO, J. and THOMPSON, DG. (Eds.). Phytochemicals for Pest Control. Washington: American Chemical Society. p. 144-154. Symposium Series, no. 658.
FOLCH, J., LESS, M. and SLORNE STANLEY, GH., 1957. A simple method for the isolation and purification of total lipids from animal tissues. Journal of Biological Chemistry, vol. 226, p. 497. PMid:13428781.

GARCIA, QS., REZENDE, JLP. and AGUIAR, LMS., 2000. Seed dispersal by bats in a disturbed area of Southeastern Brazil. Revista de Biologia Tropical, vol. 48, no. 1, p. 125-128. PMid:15266800.

HAMILTON-SMITH, E., 2000. Report on current changes in biodiversity of the Bat Cave: Naracoorte World Heritage area. South Australia: Internal report for the Department of the Environment and Heritage.

HANLEY JUNIOR, TR., BRESLIN, WJ., QUAST, JF. and CARNEY, EW., 2002. Evaluation of spinosad in a two generation dietary reproduction study using sprague-dawley rats. Toxicological Sciences, vol. 67, p. 144-152. PMid:11961227. http://dx.doi. org/10.1093/toxsci/67.1.144

KIRST, HA., 2010. The spinosyn family of insecticides: realizing the potencial of natural products research. Journal of Antibiotics, vol. 63, p. 101-111. PMid:20150928. http://dx.doi.org/10.1038/ ja. 2010.5

KIRST, HA., MICHEL, KH., MYNDERSE, JS., CHIO, EH., YAO, RC., NAKATSUKASA, WM., BOECK, LD., OCCLOWITZ, JL., PASCHAL, JW., DEETER, JB. and THOMPSON, GD., 1992. Discovery, isolation, and structure elucidation of a family of structurally unique, fermentation-derived tetracyclic macrolides. In BAKER, DR., FENYES, JG. and STEFFANS, JJ. (Eds.). Synthesis and Chemistry of Agrochemicals III. Washington: American Chemical Society. p. 214-225.

MELO, BES., BARROS, MS., CARVALHO, TF., AMARAL, TS. and FREITAS, MB., 2012. Energy reserves of Artibeus lituratus (Chiroptera: Phyllostomidae) in two areas with different degrees of conservation in Minas Gerais, Brazil. Brazilian Journal of Biology, vol. 72, no. 1, p. 181-187.

MERTZ, FP. and YAO, RC., 1990. Saccharopolyspora spinosa $s p$. nov. isolated from soil collected in a sugar mill rum still. International Journal of Systematic Bacteriology, vol. 40, p. 34-39. http://dx.doi.org/10.1099/00207713-40-1-34

MISPAGEL, C., ALLINSON, M., ALLINSON, G., ISEKI, N., GRANT, C. and MORITA, M., 2004. DDT and metabolites residues in the southern bent-wing bat (Miniopterus schreibersii bassanii) of south-eastern Australia. Chemosphere, vol. 55, p. 997-1003. PMid:15051369. http://dx.doi.org/10.1016/j. chemosphere.2003.12.008

MUSCARELLA, R. and FLEMING, TH., 2007. The role of frugivorous bats in tropical forest succession. Biological Reviews, vol. 82, no. 4, p. 573-590. PMid:17944618. http://dx.doi. org/10.1111/j.1469-185X.2007.00026.x

NORDLIE, RC., FOSTER, JD. and LANGE, AJ., 1999. Regulation of glucose production by the liver. Annual Review of Nutrition, vol. 19, p. 379-406. PMid:10448530. http://dx.doi.org/10.1146/ annurev.nutr.19.1.379

PEREIRA, FEL., 1993. Degenerações. Morte celular. Alterações do Interstício. In BRASILEIRO FILHO, GB. (Ed.). Bogliolo Patologia Geral. Rio de Janeiro: Guanabara Koogan. 220 p.

POURNOURMOHAMMADI, S., FARZAMI, B., OSTAD, SN., AZIZI, E. and ABDOLLAHI, M., 2005. Effects of malathion subchronic exposure on rat skeletal muscle glucose metabolism. Environmental Toxicology and Pharmacology, vol. 19, p. 191-196. PMid:21783476. http://dx.doi.org/10.1016/j.etap.2004.07.002 
RAHIMI, R. and ABDOLLAHI, M., 2007. A review on the mechanisms involved in hyperglycemia induced by organophosphorus pesticides. Pesticide Biochemistry and Physiology, vol. 88, p. 115-121. http://dx.doi.org/10.1016/j.pestbp.2006.10.003

REIS, NR., PERACCHI, AL., PEDRO, WA. and LIMA, IP., 2007. Morcegos do Brasil. Londrina.

REZG, R., MORNAGUI, B., KAMOUN, A., EL-FAZAA, S. and GHARBI, N., 2007. Effect of subchronic exposure to malathion on metabolic parameters in the rat. Comptes Rendus Biologies, vol. 330, p. 143-147. PMid:17303541. http://dx.doi.org/10.1016/j. crvi.2006.11.002

ROTHWELL, JT., CARSON, J., SHERWOOD, N., SHIELDS, R., HACKET, K. and BURNETT, T., 2005. Residues of spinosad in the tissues of sheep after aerosol treatment of blowfly myiasis. Australian Journal of Chemistry, vol. 83, p. 154-156.

SALGADO, VL., 1998. Studies on the mode of action of Spinosad: Insect symptoms and physiological correlates. Pesticide Biochemistry and Physiology, vol. 60, p. 91-102. http://dx.doi. org/10.1006/pest.1998.2332

SALGADO, VL., SHEETS, JJ., WATSON, GB. and SCHMIDT, AL., 1998. Studies on the mode of action of Spinosad: The internal effective concentration and the concentration dependence of neural excitation. Pesticide Biochemistry and Physiology, vol. 60, p. 103-110. http://dx.doi.org/10.1006/pest.1998.2333
SALGADO, VL. and SPARKS, TC., 2005. The spinosyns: chemistry, biochemistry, mode of action, and resistance. In GILBERT, LJ., IATROU, K. and GILL, SS. (Eds.). Comprehensive Molecular Insect Science. Oxford: Elsevier. p. 137-173.

SJÖRGREN, B., NOERDENSKJOLD, T., HOLMGEEN, H. and MOLLERSTROM, J., 1938. Beitrag zur kenntnis der leberrhythmik (glykogen, phosphor und calcium in der kaninchenleber). Pflügers Archiv, p. 240-247.

SPARKS, TC., CROUSE, GD. and DURST, G., 2001. Natural products as insecticides: the biology, biochemistry and quantitative structure-activity relationships of spinosyns and spinosoids. Pest Management Science, vol. 57, p. 896-905. PMid:11695182. http:// dx.doi.org/10.1002/ps.358

THOMPSON, GD., DUTTON, R. and SPARKS, TC., 2000. Spinosad-a case study: an example from a natural products discovery programme. Pest Management Science, vol. 56, p. 696-702.

TIMM, RM., 1994. The mammal fauna. In McDADE, LA., BAWA, KS., HESPENHEIDE, HA. and HARTSHORN, GS. La Selva: Ecology and natural history of a neotropical rain forest. Chicago: University of Chicago Press. p. 229-237.

YANO, BL., BOND, DM., NOVILLA, MN., MCFADDEN, LG. and REASOR, M.J., 2002. Spinosad insecticide: Subchronic and chronic toxicity and lack of carcinogenicity in Fischer 344 rats. Toxicological Sciences, vol. 65, p. 288-298. PMid:11812933. http://dx.doi.org/10.1093/toxsci/65.2.288 